\title{
Selenium Content and Antioxidant Potential of Some Edible Wild Mushrooms from Bandundu Area, DR Congo
}

\author{
Marina Kisuba Kabuyi ${ }^{*}$, Paulin Mutwale Kapepula ${ }^{2 *}$, Jimmy Kabeya Kabengele ${ }^{2}$, \\ Bénédicte Moni' ${ }^{1}$, Gisèle Makengo', Patricia Mbombo Mungitshi' ${ }^{2}$, Adam Tujibikila Mukuta², \\ Clement Mbadiko Mutunda', Simon Dibaluka Mpulusu3 ${ }^{3}$, Jean Paul Koto-Te-Nyiwa Ngbolua ${ }^{3}$, \\ Nadège Ngombe Kabamba ${ }^{2}$, Théophile Mbemba Fundu ${ }^{1}$
}

\footnotetext{
${ }^{1}$ Research Laboratory of Food and Nutrition (LARAN), Department of Biology, Faculty of Science, University of Kinshasa, Kinshasa XI, Democratic Republic of the Congo

${ }^{2}$ Centre d'Etudes des Substances Naturelles d' Origine Végétale (CESNOV), Faculty of Pharmaceutical Sciences, University of Kinshasa, Kinshasa XI, Democratic Republic of Congo

${ }^{3}$ Department of Biology, Faculty of Science, University of Kinshasa, Kinshasa XI, Democratic Republic of the Congo

Email: garaphmutwal@yahoo.fr
}

How to cite this paper: Kabuyi, M.K., Kapepula, P.M., Kabengele, J.K., Moni, B., Makengo, G., Mungitshi, P.M., Mukuta, A.T., Mutunda, C.M., Mpulusu, S.D., Ngbolua, J.P.K.-T.-N., Kabamba, N.N. and Fundu, T.M. (2017) Selenium Content and Antioxidant Potential of Some Edible Wild Mushrooms from Bandundu Area, DR Congo. Natural Resources, 8, 103-113. https://doi.org/10.4236/nr.2017.82008

Received: January 26, 2017

Accepted: February 17, 2017

Published: February 20, 2017

Copyright $\odot 2017$ by authors and Scientific Research Publishing Inc. This work is licensed under the Creative Commons Attribution International License (CC BY 4.0).

http://creativecommons.org/licenses/by/4.0/ (c) (i) Open Access

\begin{abstract}
Nutrition is an important aspect of public health because it is linked to many significant diseases and health problems. This work is part of the promotion of traditional foods from the Democratic Republic of Congo in general and in the province of Bandundu, in particular by assessing the selenium content and the antioxidant capacity of wild edible mushrooms. Methanolic extracts from selected mushrooms were characterized for their chemical fingerprint by TLC and their in vitro antioxidant activities using ABTS, DPPH assays. Phytochemical screening revealed the presence of alkaloids, free amines, steroids and terpenes in all species. However, Auricularia delicata and Pleurotus tuberregium contain flavonoids. All extracts displayed a good radical-scavenging activity at the concentration range $1-300 \mu \mathrm{g} / \mathrm{mL}$ in the following order: Auricularia delicata $>$ Lentinus cf cladopus $>$ Pleurotus tuberregium $>$ Marasmius buzungolo $>$ Schizophillum commune. Studied mushrooms showed the interest quantity of selenium and L. cf cladodus had the highest concentration. Moderate selenium content of these wild mushrooms associated with their important antioxidant activities could provide health benefits to Bandundu's populations in protecting against oxidative damage under different conditions including konzo.
\end{abstract}




\section{Keywords}

Antioxidant Activity, Auricularia delicata, Lentinus cf cladopus,

Marasmius buzungolo, Pleurotus tuberregium, Schizophyllum commune,

Selenium, Traditional Food

\section{Introduction}

Nutrition is an important aspect of public health because it is linked to many significant diseases and health problems. The consumption of vegetable foods has been a public health issue; based on existing research, polyphenols may be applicable to public health in primary and secondary prevention, particularly concerning diseases associated with oxidative damage such as obesity, diabetes, cardiovascular disease, and cancers [1]. Finding alternative and complementary ways to reduce the oxidative processes might have a beneficial interest in the context of developed countries.

The Democratic Republic of Congo flora in general and this of Kwilu-Kwango in the Bandundu area, in particular, is rich in unexploited traditional foods. The Kwango-Kwilu area is among the top producers of cassava, and cassava flour, the main source of carbohydrates. This region paradoxically has a specific significance due to recurring outbreaks of a neglected disease called konzo, which is a distinct neurological entity with selective upper motor neuron damage. Recent studies suggest that disease development may be mediated by oxidative damage, induced by cyanide poisoning through the ingestion of poorly processed bitter cassava [2]. Cassava and its derivatives are consumed with vegetables, squash, caterpillars, mushrooms and fish in small quantities and meat. Meat, a source of sulfur amino acids, is reserved for special occasions such as festivals and other large events. In times of famine or welding, mushrooms are indeed considered as substitute foods with meat and fish [3]. It is amazing that food, too widespread and popular in tropical Africa as wild mushrooms from the Democratic Republic of Congo, suffer from such a lack of taxonomic data, phytochemical and biological activities. For this, Mbemba et al. (2013) assessed the nutritional value of traditional foods, in order to equilibrate the diet of the population of this area severely affected by the malnutrition [4]. Among traditional foods studied by Mbemba et al. (2013), we focus our research on five species of edible wild mushrooms largely consumed by the population of the Kenge town in Bandundu area: Auricularia delicata (Mont.) Henn., Lentinus cf cladopus (Lév.), Marasmius buzungolo Singer, Pleurotus tuberregium (Fr.) Singer, Schizophyllum commune Fr. Previous studies on nutritive value and chemical composition of selected mushrooms reported that they are potentially a good source of proteins, macro and micro elements, and fibres [4] [5] [6]. Mushrooms are a source of healthy nutrients, mainly secondary metabolites, such as terpenes, steroids, phenolic compounds, but also of some primary metabolites like organic acids, peptides, and proteins.

To our knowledge, few investigations have been performed on the biological 
properties such as antioxidant capacities of mushrooms from Bandundu. The present work aimed to investigate the antioxidant activities of methanolic extracts of edible wild mushrooms using ABTS and DPPH assays. Thin Layer Chromatography (TLC) was used to achieve phytochemical analysis.

\section{Materials and Methods}

\subsection{Study Area}

Plants have been harvested in Kenge ( $\left.\mathrm{S} 04^{\circ} \mathrm{S} 1^{\prime} \mathrm{E} 16^{\circ} \mathrm{S} 8^{\prime}\right)$, a territory in PelendeNord sector, Kwango district, Bandundu Province in the Democratic Republic of the Congo. According to Koppen classification, its climate is of AW4 type. The annual average pluviometry is around $1500 \mathrm{~mm}$. The monthly average temperatures vary between $22^{\circ} \mathrm{C}$ and $24^{\circ} \mathrm{C}$; during the rainy season, the average maxima rise around $28^{\circ} \mathrm{C}$ and in the dry season around $31^{\circ} \mathrm{C}$ whereas the average minima get down between $17^{\circ} \mathrm{C}$ and $13^{\circ} \mathrm{C}$. Geologically, Kenge-Kwango formations belong to two systems, which are: Kharroo and Kalahari.

This latter covers another one, and the Kalahari system is made of layer superposing of Bateke series and of soft polymorphic and stones upon hard rock's (silicious sand stones). The Kharroo is mainly made by Kusango series (upper cretaceous). These are soft clay sandstones, red brick withargillite (clay stone) and conglomerate. The soft sandstones are made of average dimension quartz grains, well rolled, spread in a mass of slender grains [7].

\subsection{Materials}

Mushrooms: Auricularia delicata, Lentinus cf cladopus, Marasmius buzungolo, Pleurotus tuber-regium and Schizophyllum commune were harvested in the state specifically in the territory of Kenge (Bandundu) on November 2014. The collected mushrooms were identified by Professor Dibaluka S, expert of the Department of Biology, Faculty of Science, University of Kinshasa, DR Congo). The mushrooms were first dried under sunlight to avoid deterioration due to moisture, before passing through the oven. Once in the laboratory, the mushrooms were dried at $65^{\circ} \mathrm{C}$ in an oven while calculating the rate of moisture and grinding using an electric grinder. The powdered mushrooms were stored in the dark at room temperature and used for solvent extraction.

\subsection{Chemicals and Reagents}

All solvents were of analytical grade and purchased from Merck VWR (Leuven, Belgium). Gallic acid, 2, 2'-Azino-bis (3-ethylbenzothiazoline-6-sulphonic acid) (ABTS), 2-aminoethyldiphenylborat, Folin-Ciocalteu reagent and potassium persulfate were purchased from Sigma (Bornem, Belgium) purchased from Sigma-Aldrich. 1, 1-Diphenyl-2-picrylhydrazyl (DPPH) was purchased from Eastman Kodak (Rochester, NY, USA).

\subsection{Preparation of Extracts}

Methanolic extracts were prepared by maceration of $30 \mathrm{~g}$ of mushroom powder 
with $200 \mathrm{ml}$ of methanol $80 \%$. Evaporation of the solvent was performed under a reduced pressure $\left(40^{\circ} \mathrm{C}\right)$ followed by a stay of $48-72 \mathrm{~h}$ in a vacuum chamber to provide the dry extracts which were weighed and kept in hermetic and dark flasks at $4^{\circ} \mathrm{C}$.

\subsection{Phytochemical Analysis}

\subsubsection{Selenium Content}

The total selenium content was performed by a colorimetric method using 3, 3'diaminobenzidine as a complexing reagent. All selenium compounds are reduced in selenites and selenium thus converted in selenium IV preceded by mineralization. The method was based on the measurement of the yellow color formed when 3, 3'-diaminobenzidine (DAB) reacts with $\mathrm{Se}^{4+}$ [8]. Selenium VI standard was prepared daily by appropriate dilution of $\mathrm{Na}_{2} \mathrm{SeO}_{4} \cdot 10 \mathrm{H}_{2} \mathrm{O}$ to obtain $1 \mu \mathrm{g} / \mathrm{mL}$ of analytic solution.

\subsubsection{Thin Layer Chromatography (TLC) Analysis}

The phytochemical screening was performed following the standard techniques [9]. Analytical TLC of $10 \mu \mathrm{l}$ of solution for $10 \mathrm{mg} / \mathrm{ml}$ of aqueous extracts was carried out on normal phase Silica gel $60 \mathrm{~F}_{254}$ plates (Merck), using as eluent either:

a) Ethyl acetate, formic acid, glacial acetic acid and water (100:11:11:26; $\mathrm{v} / \mathrm{v} / \mathrm{v} / \mathrm{v})$.

b) Toluene/ethyl acetate $(9: 1 ; \mathrm{v} / \mathrm{v})$ [10].

Flavonoids and phenolic acids were revealed using Natural Products-PEG reagent and observed at UV-365 nm light. Chlorogenic acid, rutin, hyperoside, and isoquercitrin were used as standards. Flavonoids were detected as yelloworange fluorescent spots and phenolic acid as blue fluorescent spots; quinones owing to Borntrager reagent $\left(\mathrm{NaOH} 10 \%\right.$ or $\left.\mathrm{NH}_{4} \mathrm{OH} 10 \%\right)$; alkaloids due to Dragendorff reagent; terpenoids and steroids were revealed by using sulphuric anisaldehyde and antimony $20 \%$.

\subsubsection{Determination of Total Phenolic Content}

Total phenolic content of methanolic extracts (Methanol 80\%) extracts was determined according to the Folin-Ciocalteu method as described previously [11]. A calibration curve of gallic acid $(0.025-0.4 \mathrm{mg} / \mathrm{mL})$ was prepared, and phenolic contents were determined in triplicate from the linear regression equation of this curve. The results were expressed as milligrams of gallic acid (GA) equivalent per gram of dried matter.

\subsubsection{Flavonoid Content}

The flavonoid content of mushrooms extracts was determined by UV-Vis spectrophotometry method described previously [12]. Results are expressed in $\mathrm{mg}$ equivalent of quercetin per $\mathrm{g}(\mathrm{mg} \mathrm{QE} / \mathrm{g}$ ) of dry vegetal material using the following equation $\mathrm{y}=0.0232 \mathrm{x}+0.1535\left(\mathrm{R}^{2}=0.945\right)$.

\subsubsection{Tannins Content}

The extraction of tannins was carried out according to the adapted method used 
by Zhang et al., 2008 [13]. Tannin extract contents were quantified by vanillin method using the procedure reported by Sun et al., 1998 [14]. This method is based on the ability of vanillin to react with tannins units in the presence of acid to produce a colored complex measured at $500 \mathrm{~nm}$.

\subsection{Evaluation of Radical Scavenging Activity}

\subsubsection{ABTS Radical Scavenging Capacity}

ABTS assay was based on the method described by Tshisekedi et al. (2017) [15]. Briefly, $\mathrm{ABTS}^{\bullet+}$ radicals were generated by mixing potassium persulfate $(2.45$ $\mathrm{mM}$ ) with ABTS (7 $\mathrm{mM}$ ) and kept overnight in the dark. Working solution of $\mathrm{ABTS}^{\cdot+}$ was obtained by adding $100 \%$ methanol to have an absorbance of 0.80 $( \pm 0.02)$ at $734 \mathrm{~nm}$. The $\mathrm{ABTS}^{\bullet+}$ scavenging capacity of each extract was monitored at $734 \mathrm{~nm}$ after 30 minutes, and compared to control DMSO and positive control.

\subsubsection{DPPH Radical Scavenging Capacity}

DPPH assay was performed according to the method described previously by Tshisekedi et al. (2017) [15]. Gallic acid was used as positive control and ABTS ${ }^{\bullet+}$, DPPH scavenging activities of extracts were expressed as $\mathrm{IC}_{50}$ values. Each sample was measured in triplicate.

\section{Results and Discussion}

\subsection{Chemical Analysis}

\subsubsection{Selenium Content}

Selenium, vital to human health, is a mineral essential for the functioning of the thyroid gland and also plays a role as an enzyme cofactor in antioxidant defense. The mineral analysis showed that selenium content of studied mushrooms ranging from $2.1 \mu \mathrm{g} / 100 \mathrm{~g}$ to $5.6 \mu \mathrm{g} / 100 \mathrm{~g}$ of dry weight (Table 1 ). L. cf cladopus had the highest content followed in decreasing order by M. buzungolo, A. delicata, $P$. tuber-regiun and, S. commune.

Studies of Ifeoma et al. (2009), on analysis of the mineral composition of fungi reported for Pleurotus tuber-regium, low selenium content $(2.5 \mu \mathrm{g} / 100 \mathrm{~g})$ [16]. Studies of Mallikarjuna et al. (2013) on the mineral composition of mushrooms Lentinus and Pleurotus genus and showed high concentrations of selenium ranging from to $48 \mu \mathrm{g} / 100 \mathrm{~g}$ to $190 \mu \mathrm{g} / 100 \mathrm{~g}$, largely superior to our samples [6]. Falandysz (2008) reported that most of the edible mushroom species are selenium-poor with quantities of selenium $<100 \mu \mathrm{g} / 100 \mathrm{~g}$ dry weight.

Table 1. Ashes, selenium content and water content of studied mushrooms.

\begin{tabular}{cccccc}
\hline Parameters & $\begin{array}{c}\text { Auricularia } \\
\text { delicata }\end{array}$ & $\begin{array}{c}\text { Lentinus } \\
\text { cf. cladopus }\end{array}$ & $\begin{array}{c}\text { Marasmius } \\
\text { buzungolo }\end{array}$ & $\begin{array}{c}\text { Pleurotus } \\
\text { tuber-regium }\end{array}$ & $\begin{array}{c}\text { Schizophillum } \\
\text { commune }\end{array}$ \\
\hline Ashes $(\%)$ & $8.8 \pm 0.1$ & $2.29 \pm 0.01$ & $2.74 \pm 0.02$ & $1.04 \pm 0.02$ & $1.22 \pm 0.05$ \\
Selenium $(\mu \mathrm{g} / \mathrm{l00g})$ & $3.3 \pm 0.01$ & $5.6 \pm 0.2$ & $4.1 \pm 0.13$ & $2.2 \pm 0.01$ & $2.1 \pm 0.13$ \\
Water content $(\%)$ & 7.15 & 14.43 & 6.65 & 6.46 & 18.37 \\
\hline
\end{tabular}


Our samples contain the quantity of selenium relatively less and inferior to vegetables and fruits such as papaya, pineapple, guava, mango and raspberry which contain quantities of selenium ranging from $60 \mu \mathrm{g} / 100 \mathrm{~g}$ to $1600 \mu \mathrm{g} / 100 \mathrm{~g}$ [17]. The amount of selenium in any food varies greatly depending on the quality of the soil on which the food was produced, and cultured. Less selenium content of studied mushrooms is probably related to the poor amount of the selenium available in soils of Kwilu-Kwango district characterized by Kalahari soil type with texture and composition poor [18]. A low dietary selenium intake is associated with oxidative stress-related conditions. However studied mushrooms and others foods rich in selenium are needed to be consumed and valorized by Congolese population, especially population of Kwilu-Kwango severely affected by konzo. Bumoko et al. (2015) reported that selenium deficiency contributes to the pathogenesis of konzo through mechanisms that are responsible for oxidative damage [19].

\subsubsection{Phytochemical Screening}

The results of phytochemical screening are presented in Table 2. Alkaloids, free amines, terpenes, steroids are present in all species studied. TLC analysis of methanolic extracts showed the presence of polyphenolic compounds in all extracts. Phenolic acids were the most abundant, however, A. delicata and P. tuberregium contain flavonoids.

There exist few reports on the phytochemical screening of these Congolese wild edible mushrooms. Further chromatographic and spectroscopic studies are needed to characterize the others unknown compounds.

Results from the quantitative determination of flavonoids and total phenolic contents were obtained from the linear regression equation and are summarized in Table 3.

Flavonoids as quercitrin equivalents in milligrams per gram of dry weight (QE/g DW) and total polyphenol contents were calculated as gallic acid equivalents in milligrams per gram of dry weight (mg GAE/g DW). The total phenolic contents varied significantly $(P<0.05)$ between the studied mushrooms. Results

Table 2. Results of preliminary phytochemical screening.

\begin{tabular}{cccccc}
\hline $\begin{array}{c}\text { Secondary } \\
\text { metabolites }\end{array}$ & $\begin{array}{c}\text { Auricularia } \\
\text { delicata }\end{array}$ & $\begin{array}{c}\text { Lentinus } \\
\text { cf. cladopus }\end{array}$ & $\begin{array}{c}\text { Marasmius } \\
\text { buzungolo }\end{array}$ & $\begin{array}{c}\text { Pleurotus } \\
\text { tuber-regium }\end{array}$ & $\begin{array}{c}\text { Schizophillum } \\
\text { commune }\end{array}$ \\
\hline Alkaloids & + & + & + & + & - \\
Anthocyanins & - & - & - & - & - \\
Cardiac glycosides & - & - & - & + & - \\
Flavonoids & + & - & + & + & + \\
Free amines & + & + & - & - & - \\
Reducing sugar & - & - & - & + & + \\
Tannins & - & + & + & + & + \\
Terpenes, steroids & + & + & + & + \\
\hline
\end{tabular}


Table 3. $\mathrm{IC}_{50}$ values $(\mu \mathrm{g} / \mathrm{mL})$ on ABTS and DPPH assays, total phenolic content $(\mathrm{mg}$ $\mathrm{GAE} / \mathrm{gDW}$ ), flavonoid content (mg QE/gDW) of selected wild mushrooms (Mean $\pm \mathrm{SD}$, $\mathrm{n}=3)$.

\begin{tabular}{ccccc}
\hline & ABTS & DPPH & $\begin{array}{c}\text { Total phenolic } \\
\text { contents }\end{array}$ & $\begin{array}{c}\text { Flavonoid } \\
\text { contents }\end{array}$ \\
\hline Samples & $\mathrm{IC}_{50}(\mu \mathrm{g} / \mathrm{mL})$ & $\mathrm{IC}_{50}(\mu \mathrm{g} / \mathrm{mL})$ & $(\mathrm{mg} \mathrm{GAE} / \mathrm{gDW})$ & $(\mathrm{mg} \mathrm{QE} / \mathrm{gDW})$ \\
Auricularia delicata & $25.47 \pm 0.98$ & $76.38 \pm 0.98$ & $47.98 \pm 0.43$ & $4.38 \pm 0.23$ \\
Lentinus cf cladopus & $112.95 \pm 0.98$ & $291.07 \pm 0.98$ & $22.79 \pm 0.21$ & nd \\
Marasmius buzungolo & $187.068 \pm 0.97$ & $346.74 \pm 0.94$ & $31.68 \pm 0.29$ & nd \\
Pleurotus tuber-regium & $153.815 \pm 1,01$ & $281.19 \pm 0.95$ & $23.37 \pm 8.16$ & $0.89 \pm 0.15$ \\
Schizophylium commune & $197.242 \pm 0.94$ & $319.15 \pm 0.97$ & $15.35 \pm 0.14$ & $\mathrm{nd}$ \\
Gallic acid & $0.71 \pm 0.08$ & $1.07 \pm 0.10$ & & \\
\hline
\end{tabular}

nd $=$ not determined

showed that $A$. delicata is the sample with the highest amount of total phenolic compounds followed by M. buzungolo. Further, A. delicate gives flavonoids moderately high values compared to the others. Studies of Arbaayah (2013) on the evaluation of antiradical activity of the ethanol extract of Pleurotus spp. and Schizophillum commune showed that the variety of Pleurotus djamor was the richest with total polyphenol contents and in flavonoids [20]. Contrary to our results, Ifeoma et al. (2009) reported flavonoids in P. tuber-regium. In general, flavonoids represented a very small percentage of the total polyphenol contents in mushrooms and phenolic acids constitute their main phenolic compounds [21].

\subsection{Antioxidant Activity}

Radical scavenging activity of tested food items, determined by two different methods namely ABTS and DPPH is presented in Table 3 and is expressed as $\mathrm{IC}_{50}$ values. $\mathrm{IC}_{50}$ is the amount of antioxidant necessary to decrease the initial concentration of radical by $50 \%$. The lower $\mathrm{IC}_{50}$ value indicates a higher antioxidant activity.

Our results obtained from ABTS and DPPH assays show that the extracts were effective in the reduction of stable radicals $\mathrm{ABTS}^{\circ+}$ and $\mathrm{DPPH}^{\circ}$. These extracts had significant scavenging effects with increasing concentrations in the range of $20-350 \mu \mathrm{g} / \mathrm{mL}$ and with antiradical activities connected to their ability to scavenge free radicals according to their $\mathrm{IC}_{50}$ and gallic acid (positive control) equivalent (GA-E) values (Table 3). $\mathrm{IC}_{50}$ and GA-E values for extracts showed that $A$. delicata is the most active followed by $L$. cf cladopus, P. tuber-regium, $M$. buzungolo and $S$. commune. This strong radical scavenging activity might be attributed to their direct capacity for trapping free radicals by donating a hydrogen atom. The antioxidant activity of studied mushrooms might correlate with the total phenolic content, evaluated by means of the Folin-Ciocalteu assay, nevertheless, individual phenolic compounds could show markedly different antioxidant effects. Previous studies reported the remarkable antioxidant activity of 
wild and cultivated mushrooms [20] [21] [22] [23] [24]. By comparing with previous literature, all wild tropical studied mushroom samples showed higher antioxidant activity performed by ABTS and DPPH assays.

In our study, the antioxidant response of extracts appeared to be correlated with the method used. Extracts tested with a high GAE in ABTS assay also had a high GAE in the DPPH assay, but ABTS values appeared higher than those of DPPH in all the extracts. This can be explained by the different mechanisms of the analytical methods. ABT assay is applicable for both hydrophilic and lipophilic antioxidants while DPPH assay only hydrophilic antioxidants. In addition, some colored compounds can interfere at specific wavelengths of DPPH, leading to the underestimated antioxidant activity of extracts [25] [26].

Mushrooms are arich source of nutrients and nutraceuticals responsible for their pharmacological properties such as antioxidant, antimicrobial, immunomodulatory, antiatherogenic, and hypoglycemic activities [27] [28]. Wild mushrooms are becoming more important in our diet due to their nutritional value, related to the high protein and low fat/energy contents. Mbemba et al. (2013) reported the nutritional value of Congolese wild edible mushrooms and indicated that they were rich in proteins and certain essential amino acids, lipids, micronutrients [4]. Polyphenols have the potential to confer benefit in diverse neurodegenerative disorders associated with oxidative damage [29]. The antioxidant potential and selenium content of studied mushrooms could have a beneficial health for Congolese people, in particular, the population of KwiluKwango, an area severely affected by konzo, a permanent and non-progressive paralytic disease associated with oxidative damage.

\section{Conclusion}

Chemical analysis of studied wild edible mushrooms showed that they contain alkaloids, free amines, terpenes, steroids and phenolic compounds. A. delicata and P. tuber-regium contain also flavonoids. Methanolic extracts of studied mushrooms showed an evident antioxidant activity in the selected in vitro chemical antioxidant assays. Valorization of traditional foods of Kwilu-Kwango's area with high antioxidant capacity could contribute to providing benefits protecting against oxidative damage under different conditions including konzo. The antioxidant potential and selenium content of these wild edible mushrooms could justify their use as functional foods but further studies are needed, especially on cellular models and in vivo, to demonstrate the benefit of these extracts on nutrition and health.

\section{Acknowledgements}

The authors thank the community of Kenge for their collaboration to this work.

\section{References}

[1] Marquardt, K.C. and Watson, R.R. (2014) Polyphenols and Public Health. Polyphenols in Human Health and Disease. 
https://doi.org/10.1016/b978-0-12-398456-2.00002-5

[2] Kapepula, P.M., Mungitshi, P.M., Franck, T., Mouithys-Mickalad, A., Ngoyi, D.M., Kalenda, P.D.T., Ngombe, N.K., Serteyn, D., Tits, M., Frederich, M. and Tamfum, J. (2016) Antioxidant Potentiality of Three Herbal Teas Consumed in Bandundu Rural Areas of Congo Antioxidant Potentiality of Three Herbal Teas Consumed in. Natural Product Research, 6419, 1-4. https://doi.org/10.1080/14786419.2016.1263844

[3] Eyi Ndong, H., Degreef, J. and De Kesel, A. (2011) Champignons comestibles des forêts denses d'Afrique centrale Taxonomie et identification. ABC Taxa, 10, 262.

[4] Mbemba, T., Remacle, J., Paulus, J., Anita, A., Timi-Timi, A., Kwilu, N. and Kukwikila, P. (2013) Aliments et denrées alimentaires traditionnels du Bandundu en R. D. Congo. Répertoire et composition en nutriments. L'Harmattan RDC, 317.

[5] Hanson, A.M., Hall, M.B., Porter, L.M. and Lintzenich, B. (2006) Composition and Nutritional Characteristics of Fungi Consumed by Callimico goeldii in Pando, Bolivia. International Journal of Primatology, 27, 323-346. https://doi.org/10.1007/s10764-005-9014-Z

[6] Mallikarjuna, S.E., Ranjini, A., Haware, D.J., Vijayalakshmi, M.R., Shashirekha, M.N. and Rajarathnam, S. (2013) Mineral Composition of Four Edible Mushrooms. Journal of Chemistry, 2013, 1-5. https://doi.org/10.1155/2013/805284

[7] Bukatuka, C.F., Ngombe, N.K., Mutwale, P.K., Moni, B.M., Makengo, K.G., Pambu, L.A., Bongo, N.G., Mbombo, M.P., Musuyu, M.D., Maloueki, U., Koto-Te-Nyiwa Ngbolua, J.P. and Mbemba, T.F. (2016) Bioactivity and Nutritional Values of Some Dioscorea Species Traditionally Used as Medicinal Foods in Bandundu, DR Congo. European Journal of Medicinal Plants, 14, 1-11. https://doi.org/10.9734/EJMP/2016/25124

[8] Mabeyo, P.E., Manoko, M.L.K., Gruhonjic, A., Fitzpatrick, P.A., Landberg, G., Erdélyi, M. and Nyandoro, S.S. (2015) Selenium Accumulating Leafy Vegetables Are a Potential Source of Functional Foods. International Journal of Food Science, 2015, 1-9. https://doi.org/10.1155/2015/549676

[9] Harbone, J.B. (1973) Méthodes phytochimiques, Londres. Chapman and Hall, Ltd., 188.

[10] Wagner, H., Bauer, R., Melchart, D., Xioa, P.-G. and Staudinger, A. (2013) Chromatographic Fingerprint Analysis of Herbal Medicinal: Thin-Layer High Performance Liquid Chromatography of Chinese Drugs. Springer International Publishing, Vol. 3.

[11] Anagnostopoulou, M., Kefalas, P., Papageorgiou, V.P., Assimopoulou, A.N. and Boskou, D. (2006) Radical Scavenging Activity of Various Extracts and Fractions of Sweet Orange Peel (Citrus sinensis). Food Chemistry, 94, 19-25.

https://doi.org/10.1016/j.foodchem.2004.09.047

[12] Adedapo, A., Jimoh, F.O., Koduru, S., Afolayan, A.J. and Masika, P.J. (2008) Antibacterial and Antioxidant Properties of the Methanol Extracts of the Leaves and Stems of Calpurnia aurea. BMC Complementary and Alternative Medicine, 8, 53. https://doi.org/10.1186/1472-6882-8-53

[13] Zhang, S.Y., Zheng, C.G., Yan, X.Y. and Tian, W.X. (2008) Low Concentration of Condensed Tannins from Catechu Significantly Inhibits Fatty Acid Synthase and Growth of MCF-7 Cells. Biochemical and Biophysical Research Communications, 371, 654-658. https://doi.org/10.1016/j.bbrc.2008.04.062

[14] Sun, B., Ricardo-da-Silva, J.M. and Spranger, I. (1998) Critical Factors of Vanillin Assay for Catechins and Proanthocyanidins. Journal of Agricultural and Food Chemistry, 46, 4267-4274. https://doi.org/10.1021/jf980366j 
[15] Tshibangu, P.T., Kapepula, P.M., Kapinga, M.J.K., Tujibikila, A., Kalenda, D.T., Tchinda, A.T., Mouithys-Mickalad, A., Jansen, O., Ciekiewicz, E., Tits, M., Angenot, L. and Frederich, M. (2017) Antiplasmodial Activity of Heinsia crinita (Rubiaceae) and Identification of New Iridoids. Journal of Ethnopharmacology, 196, 261-266. https://doi.org/10.1016/j.jep.2016.11.041

[16] Ifeoma, I., Ikechukwu, A., Princess, C. and Henry, I. (2009) Phytochemical Composition of Pleurotus tuberregium and Effect of Its Dietary Incorporation on Body/Organ Weights and Serum Triacylglycerols in Albino Mice. Journal of Medicinal Plants Research, 3, 939-943.

[17] Raymond, J. (1983) Biochemistry of Selenium. Plenum Press, New York, 341.

[18] Ministère du Plan (2005) Monographie de la province du Bandundu. https://www.google.cd/?gws_rd=cr,ssl\&ei=3v6JWLrqI8iXgAaf45-wDw\#q=Minist\% C3\%A8re+du+plan.+2005.+Monographie+de+la+province+du+Bandundu

[19] Bumoko, G.M.-M., Sadiki, N.H., Rwatambuga, A., Kayembe, K.P., Okitundu, D.L., Mumba Ngoyi, D. and Tshala-Katumbay, D. (2015) Lower Serum Levels of Selenium, Copper, and Zinc Are Related to Neuromotor Impairments in Children with Konzo. Journal of the Neurological Sciences, 349, 149-153. https://doi.org/10.1016/j.jns.2015.01.007

[20] Arbaayah, H. and Umi Kalsom, Y. (2013) Antioxidant Properties in the Oyster Mushrooms (Pleurotus spp.) and Split Gill Mushroom (Schizophyllum commune) Ethanolic Extracts. Mycosphere, 4, 661-673. https://doi.org/10.5943/mycosphere/4/4/2

[21] Reis, F.S., Martins, A., Barros, L. and Ferreira, I.C.F.R. (2012) Antioxidant Properties and Phenolic Profile of the Most Widely Appreciated Cultivated Mushrooms: A Comparative Study between in Vivo and in Vitro Samples. Food and Chemical Toxicology, 50, 1201-1207. https://doi.org/10.1016/j.fct.2012.02.013

[22] Wong, J.Y. and Chye, F.Y. (2009) Antioxidant Properties of Selected Tropical Wild Edible Mushrooms. Journal of Food Composition and Analysis, 22, 269-277. https://doi.org/10.1016/j.jfca.2008.11.021

[23] Puttaraju, N.G., Venkateshaiah, S.U., Dharmesh, S.M., Urs, S.M.N. and Somasundaram, R. (2006) Antioxidant Activity of Indigenous Edible Mushrooms. Journal of Agricultural and Food Chemistry, 54, 9764-9672. https://doi.org/10.1021/jf0615707

[24] Liu, Y., Sun, J., Luo, Z., Rao, S., Su, Y., Xu, R. and Yang, Y. (2012) Chemical Composition of Five Wild Edible Mushrooms Collected from Southwest China and Their Antihyperglycemic and Antioxidant Activity. Food and Chemical Toxicology, 50, 1238-1244. https://doi.org/10.1016/j.fct.2012.01.023

[25] Arnao, M.B. (2001) Some Methodological Problems in the Determination of Antioxidant Activity Using Chromogen Radicals: A Practical Case. Trends in Food Science and Technology, 11, 419-421. https://doi.org/10.1016/S0924-2244(01)00027-9

[26] Floegel, A., Kim, D.O., Chung, S.J., Koo, S.I. and Chun, O.K. (2011) Comparison of ABTS/DPPH Assays to Measure Antioxidant Capacity in Popular Antioxidant-Rich US Foods. Journal of Food Composition and Analysis, 24, 1043-1048. https://doi.org/10.1016/j.jfca.2011.01.008

[27] Barros, L., Cruz, T., Baptista, P., Estevinho, L.M. and Ferreira, I.C.F.R. (2008) Wild and Commercial Mushrooms as Source of Nutrients and Nutraceuticals. Food and Chemical Toxicology, 46, 2742-2747. https://doi.org/10.1016/j.fct.2008.04.030

[28] Guillamón, E., García-lafuente, A., Lozano, M., Arrigo, M.D., Rostagno, M.A., Villares, A. and Alfredo, J. (2010) Edible Mushrooms: Role in the Prevention of Cardiovascular Diseases. Fitoterapia, 81, 715-723. 
https://doi.org/10.1016/j.fitote.2010.06.005

[29] Vauzour, D., Kerr, J. and Czank, C. (2013) Plant Polyphenols as Dietary Modulators of Brain Functions. In: Watson, R., Preedy, V.R. and Zibadi, S., Eds., Polyphenols in Human Health and Disease, Vol. 1, Elsevier, Amsterdam, 357-370.

Submit or recommend next manuscript to SCIRP and we will provide best service for you:

Accepting pre-submission inquiries through Email, Facebook, LinkedIn, Twitter, etc. A wide selection of journals (inclusive of 9 subjects, more than 200 journals)

Providing 24-hour high-quality service

User-friendly online submission system

Fair and swift peer-review system

Efficient typesetting and proofreading procedure

Display of the result of downloads and visits, as well as the number of cited articles Maximum dissemination of your research work

Submit your manuscript at: http://papersubmission.scirp.org/

Or contact nr@scirp.org 